\title{
compassion and education: a review
}

tim sprod ${ }^{1}$

university of tasmania - austrália

Now, more than ever, many seem to say, we need more compassion in this world. Andrew Peterson starts his book by instancing a number of these calls, and few would deny that events which must have happened since he finished his text, such as the election of Donald Trump and Brexit, make the need for compassion even more urgent. But what is compassion, and how do we educate children to be more compassionate? These two questions guide the structure of the Peterson's book.

Andrew Peterson is Professor of Civic and Moral Education at Canterbury Christ Church University, UK, and an Adjunct Professor of Education at the University of South Australia. Much of his previous work has been in the areas of citizenship education and virtue ethics inspired character education. This book is thus exploring one of the more important virtues that underpins both citizenship and being a decent human being. In emphasizing this, Peterson explicitly asserts that promoting the eudaimonia of people and communities - not producing better workers - should be the central aim of education.

Having set the scene for an inquiry into compassion in the first chapter, the next four chapters are aimed at the first question: how are we to understand compassion? In a careful philosophical analysis, Peterson unpacks a number of important aspects of the concept. Primary among these is his claim, well supported, that compassion is an Aristotelian virtue, rather than merely a feeling or emotion. As a virtue, it is based in the emotions, but also requires elements of cognition and volition. Practical wisdom - Aristotle's phronesis - is needed since compassion requires (inter alia) deliberation about how situations stand in relation to the emotions we feel, and a decision if and how to act compassionately in response. Surely this is right, though I feel that Peterson does underplay the extent

\footnotetext{
${ }^{1}$ E-mail: timsprod3@gmail.com
} 
to which emotions in themselves are judgements, which then feed into the more explicit decision making of practical wisdom.

In a closer look at the emotional aspects of compassion, Peterson identifies four important emotional responses: pity, sympathy, empathy... and anger. On the face of it, anger is often considered a negative emotion, but Aristotle famously said "anybody can become angry - that is easy, but to be angry with the right person and to the right degree and at the right time and for the right purpose, and in the right way - that is not within everybody's power and is not easy". In this context, Peterson identifies compassionate anger as being of the right sort. Surely this is correct: anger can spur us to action, especially against injustice.

This volitional aspect of the emotions (and hence the virtues) is important: compassion without considered action is ineffective. The consideration is necessary: actions must be thought through in the context of the situation so as to have a compassionate outcome.

In his final theoretical chapter, Peterson explores a somewhat unexpected issue: the connections between compassion and the self. It is easy to conceive of compassion as being inherently other-directed. Yet, perhaps most clearly through the empathy element of putting oneself in the shoes of the other, the self is inherently involved. Through close analysis of Rousseau's distinction between amour propre and amour de soi, and Aristotle's account of self-love, Peterson convincingly argues that self-compassion is central to compassion for others. Though he does not make the point explicitly, such an account fits very well with communitarian theories of the self: we cannot be selves unless we develop within a community of others.

These theoretical chapters prepare us to address the second question: how should we go about educating compassionate children? Peterson advances answers of two sorts: at the classroom level, and at the whole school level. Very usefully, he points out that we are not setting out to teach compassion to those who don't have it. Such a stance he calls the deficit model (a phrase that, in this context, I would ascribe to Gareth Matthews, though Peterson does not reference him). As Matthews said, schools (and adults in general) are prone to falling into 
thinking that they are producing some desirable end from scratch, when they are merely strengthening it, on all sorts of issues. Children, teachers, schools and the communities in which they live are already compassionate in varied ways: the challenge is to provide opportunities to fine tune both an understanding of what compassion is (learning about), and how to act compassionately more often, or in better ways (learning for). Quite rightly, he points out the complexity of such a task.

Those of us who teach will find his chapter 6 on pedagogy of interest, though he does say "While I hope that the contentions offered here will be of some practical value, they will only be as such if they are taken up, refined and appropriated in ways shaped by the particular contexts in which educators work and young people live" (p. 112). He is right: this chapter is still pitched more at the philosophical level than the practical. It does not get very far into the details of what to do.

Nevertheless, it contains much of interest. Peterson identifies, and discusses, two powerful pedagogical approaches for teaching compassion: narratives and intersubjective communications. Though he does not quite explicitly say so, there are good grounds for thinking that the combination of the two, into a community of inquiry triggered by good literature, may be even more powerful than each on their own.

Narratives, he holds, have distinctive virtues: they can strengthen students' ability to imaginatively reconstruct how others see the world, through access to the internal processes of the characters. Yet we need characters that are not cardboard cutout saints: children learn better not by imitation but by ethical reflection. Saintly models do not build the practical wisdom to judge what's worth imitating. Narratives that contain moral complexity, when competently reflected upon, do. As Peterson has earlier noted, and as I argued in my Philosophical Discussions in Moral Education, to understand Aristotle as arguing for imitative habituation, followed at a later age by practical wisdom, gives little guidance as to which character traits to habituate, and how to express them in new contexts. 
Competently reflected upon, I said above. Narratives, powerful as they are, can do not more than offer models of reflection which, as Peterson argues in relation to moral exemplars, do not give practice in how to actually reflect. Here is an important role for intersubjective communications or, as many of us might say, communities of inquiry. I have to say that I was surprised, given Peterson's role as a co-editor of the online Journal of Philosophy in Schools, to find no reference in this book to Lipman, Sharp or Matthews - or, indeed, anybody working in the broad philosophy for/with children/philosophy in schools field.

Peterson has a number of useful things to say about dialogue, both its general strengths, and its advantages in relation to compassion. The former include building and practising practical wisdom and communicative abilities, and being a means to recognize the perspectives, circumstances, sentiments and goals of others. Among the latter are its ability to build the capacities needed for compassion, such as authenticity and sincerity, in a dialogue regulated by empathy, care and eudaimonistic judgement (a phrase he takes from Martha Nussbaum - deciding how to live a flourishing life, and to help others to do so too).

Finally, Peterson makes a plea for paying attention to the ways in which teachers, parents and communities can strengthen schools as compassionate institutions. In particular, he urges teachers to become more aware of their moral role, to seek - and be offered - proper preparation for carrying out that role, and to work in partnership with families and the broader community.

In summary, the theoretical section of this book offers a very careful and helpful analysis of one of the virtues we ought to be seeking to develop in students. There are other virtues, of course, and many of the broader points Peterson makes can be applied to them as well. In arguing for the central role of practical wisdom and judgement, Peterson places himself firmly in what might be called the progressive wing of the character education movement, as opposed to those whose idea of character education seems to be largely 'do what I tell you to do': habituation before practical wisdom, which somewhat mysteriously appears later. When it comes to the nitty-gritty of how to achieve this in schools, while 
teachers (rather than philosophers) might wish that they had been pointed more towards 'how-to' guides, Peterson's arguments are sound, and would prove very useful for anyone seeking to construct a program that aimed, among the other virtues, at strengthening children's compassion.

\section{references}

PETERSON, Andrew. Compassion and Education: Cultivating Compassionate Children, Schools and Communities. London: Palgrave Macmillan, 2017. pp.180 + ix. 